\title{
Formulation of Value Enriched Probiotic Fruit Yoghurt
}

\author{
V. Meenakshi*, Suganya and T. Umamaheswari \\ Community Science College and Research Institute, Madurai, Tamil Nadu Agricultural \\ University, Tamil Nadu, India \\ *Corresponding author
}

\section{A B S T R A C T}

Keywords

Probiotics,

Syneresis, Fruit yoghurt

Article Info

Accepted:

12 February 2018

Available Online:

10 March 2018
This study aimed at standardization of plain and probiotic fruit yoghurt by blending with fruits such as banana, papaya, sapota at a ratio of 5\%,10\% and 15\%. Among the different fruits used banana, sapota incorporated fruit pulp secured higher sensory scores whereas papaya Plain probiotic yoghurt was prepared using three different probiotic cultures such as Lactobacillus plantarum NCDC 25, Lactobacillus casei NCDC 298, Lactobacillus rhamnosus, NCDC 19 along with yoghurt culture. Based on the sensory evaluation probiotic yoghurt prepared using Lactobacillus casei along with yoghurt culture was found to be highly acceptable. Similarly probiotic fruit yoghurt using Lactobacillus casei was prepared using the fruits such as banana and sapota @ 5\%,10\% and 15\% and stored at refrigeration condition for 14 days to study the physico-chemical and organoleptic changes over storage period. Probiotic yoghurt with $10 \%$ fruit pulp had secured highest value for sensory score. Acceptable level of acidity was maintained after 14 days of storage in banana $(0.93 \%)$ than control sample $(1.30 \%)$. Probiotic banana yoghurt had maximum probiotic count $21 \times 10^{8}$ than other samples at the end of 14 days of storage.

\section{Introduction}

Yoghurt is a product obtained by the lactic fermentation of whole, skimmed or standardized milk by action of Lactobacillus delbrueckii ssp. bulgaricus and Streptococcus thermophilus, and can be accompanied by other lactic bacteria which, for their part, contribute to the characteristics of the final product. Yoghurt is more nutritious than many other fermented milk products because it contains a high level of milk solids in addition to nutrients developed during the fermentation process. Yogurt is being enjoyed everywhere in the world for its beneficial properties. It is easily digestible, has high nutritional value, and has also therapeutic properties. Yoghurt is nutritionally rich in protein, calcium, riboflavin, vitamin $\mathrm{B}_{6}$ and vitamin $\mathrm{B}_{12}$.

Yoghurt is part of the diet in south eastern Europe and middle east for millennia and is now part of the dairy counters even in smallest grocery stores in many countries (Kalab, 2000). In India yoghurt was prepared in earthen pots by adding sugar and small amount of starter culture which was kept overnight. Fruit yoghurt, a popular type of yoghurt is like by masses and is known as fruit stirred yoghurt. The FAO/ WHO 
recommendations for fruit yoghurt are fruit content between 5 and 15\%.Yoghurt prepared by adding seasonal fruits are very attractive. Addition of fruits makes it more delicious.

For many years only plain yoghurt was available in the world market. Recently, popularity of yoghurt is increased due to its fortification with sugar and fruits. Now-a-day there is a good demand for fruit yoghurt. Sweet fruit based yoghurt is preferred by children, adolescents and the aged. Though we eat dahi, fruits are rarely added in to it. There is great scope to popularize yoghurt/dahi particularly fruit yoghurt/dahi in India. Yoghurt due to changing food habits, several kinds of yoghurt have been tried out with fruits, nuts and other plant milks. The objective of the present study was to prepare probiotic fruit yoghurt using banana, sapota, guava and mango and to assess the physicochemical, nutritional, microbiological and organoleptic characteristics of fruit yoghurt.

\section{Materials and Methods}

Toned milk, Fruits for pulp preparation, sugar was collected from local market. Probiotic cultures such as Lactobacillus plantarum NCDC 25, Lactobacillus casei NCDC 298, Lactobacillus rhamnosus, NCDC 19, and yoghurt culture NCDC-260 were obtained from Experimental Dairy and National Collection of Dairy Cultures (NCDC), of the National Dairy Research Institute (NDRI), Karnal. Skim milk powder was procured from M/s ILECO, Madurai.

\section{Maintenance of cultures}

During the study period, the cultures were maintained in sterilized reconstituted skim milk (12 g Skimmed Milk Powder in $100 \mathrm{ml}$ distilled water) tubes. The propagation of the cultures (at $37^{\circ} \mathrm{C}$ ) was done at weekly intervals to maintain their activity. The cultures were stored at $5^{\circ} \mathrm{C}$ between the transfers.

\section{Analysis}

The probiotic plain and probiotic fruit yoghurts were analyzed for chemical, physical, microbiological and sensory properties.

\section{Physico-chemical properties of yoghurt during storage}

The physicochemical parameters viz., TSS, $\mathrm{pH}$, acidity, syneresis, viscosity, protein, fat, content of the samples was analyzed as per AOAC (2000) methods. The $\mathrm{pH}$ was measured with a $\mathrm{pH}$ meter. Acidity was titrated by $0.1 \mathrm{~N} \mathrm{NaOH}$ solution and expressed in terms of \% lactic acid. The susceptibility of yogurt to syneresis was determined using drainage method.

\section{Syneresis}

Degree of syneresis expressed as proportion of free whey was measured. About $10 \mathrm{~g}$ of sample of yoghurt was placed on a filter paper resting on the top of a funnel. After $10 \mathrm{~min}$ of drainage the quantity of remained yoghurt was weighed and syneresis was calculated as follows:

Weight of initial sample Weight of sample after filtration Free whey $(\mathrm{g} / 100 \mathrm{~g})=$ Weight of initial sample

\section{Viscosity}

Measurements of viscosity were done with Brookfield DV-E Viscometer and Spindle No 64 at $6 \mathrm{rpm}$ was used for all samples. Viscosity was monitored during storage at $4^{\circ} \mathrm{C}$ after 1, 7 and 14 days. Results were recorded in centipoise (cP) after 0.5 minutes of 
shearing. The viscosity of yoghurt was analysed periodically.

\section{Microbial analysis of developed product}

The following media were selected as suitable for enumeration: MRS agar incubated at $42^{\circ} \mathrm{C}$ for $24 \mathrm{~h}$ was applied for probiotic count and PDA agar was used for yeast and mould count. Microbiological count data are expressed as Colony Forming Units (CFU) per gram of yoghurt. Four dilutions were carried out to determine the number of bacteria during storage.

\section{Sensory evaluation}

The colour and appearance, flavor, texture, taste and overall acceptability of all yogurt samples were evaluated sensorial by a semi trained panel of 30 members using a Nine point score system with score ranging from 9 to 1 where score represented like extremely and dislike extremely respectively.

\section{Results and Discussions}

\section{Standardization of plain yoghurt}

The freshly activated yoghurt culture NCDC 260 was inoculated in toned milk (fat $-3 \%$ SNF-8.5\%) @ 1\% and $2 \%$ level and incubated at $40 \pm 2^{0} \mathrm{C}$ for the preparation of yoghurt. Time taken for clean curdling was 5 hours. The acidity of yoghurt @ 1\% and 2\% level was $0.81 \mathrm{~g} \%$ and $0.85 \mathrm{~g} \%$ respectively. From the trial and sensory evaluation, it was found that $2 \%$ level of yoghurt inoculum used was found to be most acceptable. The acidity of plain yoghurt confirms with the FSSAI standards. The data obtained was statistically analyzed for mean \pm standard error. From the statistical analysis, it was found that overall acceptability of yoghurt prepared with $2 \%$ inoculum level was found to be highly acceptable (Table 1).

\section{Standardization of plain fruit yoghurt (Stirred yoghurt)}

The standardized plain yoghurt with $2 \%$ level of inoculums was added with different fruits for the development of plain fruit yoghurt. The fruits such as banana, sapota, papaya were taken for the preparation of plain fruit yoghurts since banana, papaya and sapota are easily available and mostly consumed fruits.

Banana and Sapota is an important source of antioxidants (vitamin C, A and E) and calcium, magnesium and potassium. Papaya is characterized by high amount of proteolytic enzyme like papain and chmyopapain, which help in digestion and high amount of $\beta$ carotene, phenol, anti-oxidant and minerals. Blending of banana, papaya and sapota in yoghurt would produce balanced and enjoyable food. However, banana, papaya and sapota could be used in the production of fruit yogurts that would reduce the postharvest loss also.

\section{Standardization of plain banana fruit yoghurt (Stirred)}

The standardized yoghurt was blended with banana pulp @5\%,10\% and 15\% and $6 \mathrm{ml}$ of sugar solution (TSS- $62^{0} \mathrm{bx}$ ). It was then evaluated by 9 point hedonic scale. The TSS of the banana yoghurt ranges between 13 and 18. From the sensory evaluation it was found that banana fruit yoghurt @ $10 \%$ level of incorporation was found to be highly acceptable.

\section{Standardization of plain papaya fruit yoghurt (Stirred)}

The standardized yoghurt was blended with papaya pulp@5\%,10\% and 15\% and $6 \mathrm{ml}$ of sugar solution (TSS- $62^{0} \mathrm{bx}$ ). It was then evaluated by 9 point hedonic scale. The TSS of the papaya yoghurt ranges from 10 to 13 . 
From the sensory evaluation it was found that papaya fruit yoghurt was recorded to be highly unacceptable.

\section{Standardization of plain sapota yoghurt (Stirred)}

The standardized yoghurt was blended with sapota pulp@5\%,10\% and 15\% and $6 \mathrm{ml}$ of sugar solution (TSS- 62 bx). It was then evaluated by 9 point hedonic scale. From the sensory evaluation it was found that sapota fruit yoghurt @10\% level of incorporation was found to be highly acceptable.

\section{Standardization of probiotic yoghurt}

The freshly activated yoghurt culture NCDC 260 and probiotic cultures such as Lactobacillus rhamnosus NCDC 19, Lactobacillus caesi NCDC 298, Lactobacillus plantarum NCDC 25 was inoculated in toned milk (fat $-3 \%$ SNF $-8.5 \%$ ) in $1: 1$ ratio and incubated at $40 \pm 2^{0} \mathrm{C}$ for the preparation of probiotic yoghurt. Time taken for complete curdling was 5 hours. The acidity of probiotic yoghurt prepared using L. rhamnosus NCDC 19 was $0.91 \mathrm{~g} / 100 \mathrm{~g}$, L. casei NCDC 298 was $0.87 \mathrm{~g} / 100 \mathrm{~g}$ and L. plantarum NCDC 25 was $0.99 \mathrm{~g} / 100 \mathrm{~g}$. The prepared probiotic fruit yoghurt was sensorarily evaluated.

From the sensory evaluation (Table 3) and statistical analysis, it was found that probiotic yoghurt prepared with $L$. casei was highly acceptable. Hence the standardization of probiotic fruit yoghurt was tried out using probiotic culture L. casei.

\section{Standardization of probiotic fruit yoghurt}

To the prepared probiotic yoghurt from $L$. caesi NCDC 298, fruit pulp such as banana, sapota@5,10,15 per cent and $6 \mathrm{ml}$ of sugar solution (TSS- $62^{\circ}$ Brix) was added and subjected to sensory evaluation (Table 4).
The viscosity of probiotic fruit yogurt prepared from fruits such as banana (11400 $\mathrm{cP})$, mango $(8300 \mathrm{cP})$ was noted to be high, while minimum value $(4400 \mathrm{cP})$ was observed control $(4450 \mathrm{cP})$ at the initial period. Viscosity of probiotic fruit and control yoghurt was decreased during storage. At the end of $14^{\text {th }}$ day of storage, the probiotic banana (7000 cP) and sapota (1900 cP) had higher viscosity than the control $(700 \mathrm{cP})$. Maximum viscosity was maintained in probiotic banana and sapota yoghurt. This is in accordance with the results of Lee et al., (2007), Supavititpatana et al., (2010) (Table 5).

The reason for low reduction in fruit yoghurt is the presence of pectin and fructose which inturn improve consistency and viscosity of yogurt by getting mixed with, and mouth fell is improved. Pectin is reversely absorbed on casein and increases steric repulsion, and thus aggregation is decreased (Nongonierma et al., 2007). Amount of syneresis is volume of water oozed out on the surface of yogurt. At the initial day of the storage period the syneresis of probiotic banana yoghurt is low $(6.2 \%)$ followed by probiotic sapota $(21.4 \%)$ than control (30\%). Synersis was found to be decreased with the addition of fruit pulp. In the present study, the syneresis of all the probiotic fruit yoghurt showed an increasing trend till $5^{\text {th }}$ day of storage and after wards a decreasing trend was observed. Nafiseh Vahedi et al., (2008) reported a decrease in syneresis in apple yoghurt until $14^{\text {th }}$ day of storage and an increase until $28^{\text {th }}$ day of storage.

Amaya-Liano et al., (2008) stated that low solid content, high temperature of incubation and inadequate storage condition could be possible reasons of increased synersis value in yogurt. These results are in conformation with the results of several researchers wherein they stated that the rate of syneresis is directly proportional to acidity. 
Flow Diagram for the formulation of probiotic fruit yoghurt

Toned Milk (3\% fat, $8.5 \% \mathrm{SNF})$

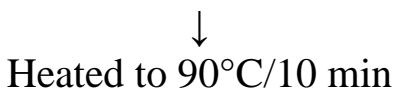

Cooling to $40 \pm 2^{\circ} \mathrm{C}$

Inoculation with culture (yoghurt culture NCDC 260 and

Probiotic culture Lactobacillus caesi NCDC 298 (1:1) @2 \%)

Incubation at $\left(40 \pm 2^{\circ} \mathrm{C}\right)$ for 5 hours

$\downarrow$

Breaking the firm curd by blending for a min

Addition of Sugar syrup

$\downarrow$

Addition of fruit pulp (banana/ sapota @ 5, 10, \& $15 \%$ )

\section{Uniform mixing}

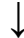

Filling

$\downarrow$

Probiotic fruit Yoghurt (Refrigeration at $4 \pm 1^{\circ} \mathrm{C}$ )

Table.1 Mean sensory characteristics of plain yoghurt

\begin{tabular}{|l|}
\hline Quality parameters \\
\hline Colour and Appearance \\
\hline Flavour \\
\hline Consistency \\
\hline Taste \\
\hline Overall acceptability \\
\hline
\end{tabular}

\section{Yoghurt (1 \% level inoculum)}

\begin{tabular}{|c|c|}
\hline & inoculum) \\
\hline $8.7 \pm 0.11$ & $8.6 \pm 0.13$ \\
\hline $8.6 \pm 0.17$ & $8.2 \pm 0.25$ \\
$7.8 \pm 0.21$ & $8.3 \pm 0.23$ \\
$8.2 \pm 0.17$ & $8.0 \pm 0.19$ \\
\hline
\end{tabular}

Table.3 Mean sensory characteristics of probiotic yoghurt

\begin{tabular}{|l|c|c|c|c|}
\hline Quality parameters & $\begin{array}{c}\text { Control (Plain } \\
\text { probiotic } \\
\text { yoghurt) }\end{array}$ & $\begin{array}{c}\text { Probiotic yoghurt } \\
\text { prepared using } \\
\text { L. rhamnosus }\end{array}$ & $\begin{array}{c}\text { Probiotic yoghurt } \\
\text { prepared using } \\
\text { L.casei }\end{array}$ & $\begin{array}{c}\text { Probiotic yoghurt } \\
\text { prepared using } \\
\text { L.plantarum }\end{array}$ \\
\hline Colour \& Appearance & $8.5 \pm 0.17$ & $8.1 \pm 0.19$ & $8.3 \pm 0.16$ & $8.5 \pm 0.17$ \\
\hline Flavour & $8.3 \pm 0.16$ & $8.0 \pm 0.16$ & $8.3 \pm 0.32$ & $8.3 \pm 0.16$ \\
\hline Consistency & $8.3 \pm 0.32$ & $7.8 \pm 0.19$ & $8.0 \pm 0.22$ & $8.3 \pm 0.32$ \\
\hline Taste & $8.0 \pm 0.22$ & $8.0 \pm 0.16$ & $8.5 \pm 0.22$ & $8.0 \pm 0.21$ \\
\hline Overall acceptability & $8.2 \pm 0.26$ & $8.1 \pm 0.19$ & $8.6 \pm 0.28$ & $8.2 \pm 0.21$ \\
\hline
\end{tabular}


Table.2 Mean sensory characteristics on quality of plain yoghurt, yoghurt prepared using banana, sapota and papaya at different incorporation levels $(5,10$ and $15 \%)$

\begin{tabular}{|c|c|c|c|c|c|c|c|c|c|c|c|c|}
\hline Quality parameters & Control & $\begin{array}{l}\text { Banana } \\
\text { fruit } \\
\text { Yoghurt } \\
(5 \%)\end{array}$ & $\begin{array}{l}\text { Banana } \\
\text { fruit } \\
\text { Yoghurt } \\
(10 \%)\end{array}$ & $\begin{array}{l}\text { Banana } \\
\text { fruit } \\
\text { Yoghurt } \\
(15 \%)\end{array}$ & Control & $\begin{array}{l}\text { Sapota } \\
\text { fruit } \\
\text { Yoghurt } \\
(5 \%)\end{array}$ & $\begin{array}{l}\text { Sapota } \\
\text { fruit } \\
\text { Yoghurt } \\
(10 \%)\end{array}$ & $\begin{array}{l}\text { Sapota } \\
\text { fruit } \\
\text { Yoghurt } \\
(15 \%)\end{array}$ & Control & $\begin{array}{l}\text { Papaya } \\
\text { fruit } \\
\text { Yoghurt } \\
(5 \%)\end{array}$ & $\begin{array}{l}\text { Papaya } \\
\text { fruit } \\
\text { Yoghurt } \\
(10 \%)\end{array}$ & $\begin{array}{l}\text { Papaya } \\
\text { fruit } \\
\text { Yoghurt } \\
(15 \%)\end{array}$ \\
\hline Colour \& Appearance & $8.5 \pm 0.17$ & $8.1 \pm 0.19$ & $8.2 \pm 0.21$ & $8.6 \pm 0.28$ & & & & & & & & \\
\hline Flavour & $8.3 \pm 0.16$ & $8.0 \pm 0.22$ & $8.2 \pm 0.21$ & $8.3 \pm 0.28$ & & & & & & & & $8.1 \pm 0.18$ \\
\hline Consistency & $8.3 \pm 0.32$ & $7.8 \pm 0.19$ & $8.0 \pm 0.16$ & $8.1 \pm 0.33$ & $8.3 \pm 0.32$ & $7.8 \pm 0.19$ & $8.3 \pm 0.32$ & $8.3 \pm 0.32$ & $8.3 \pm 0.31$ & $7.2 \pm 0.20$ & $7.3 \pm 0.22$ & $7.2 \pm 0.20$ \\
\hline Taste & $8.0 \pm 0.22$ & $8.0 \pm 0.16$ & $8.2 \pm 0.21$ & $8.6 \pm 0.39$ & $8.0 \pm 0.21$ & $8.0 \pm 0.16$ & $8.0 \pm 0.16$ & $8.0 \pm 0.16$ & $7.8 \pm 0.29$ & $7.7 \pm 0.20$ & $7.7 \pm 0.26$ & $7.8 \pm 0.29$ \\
\hline Overall acceptability & $8.2 \pm 0.26$ & $8.1 \pm 0.19$ & $8.3 \pm 0.19 *$ & $8.3 \pm 0.33^{*}$ & $8.2 \pm 0.21$ & $8.1 \pm 0.19$ & $8.6 \pm 0.16^{*}$ & $8.2 \pm 0.21$ & $8.3 \pm 0.22$ & $7.7 \pm 0.20$ & $7.8 \pm 0.19$ & $7.5 \pm 0.22$ \\
\hline
\end{tabular}

The data obtained was statistically analyzed for mean \pm standard error. From the statistical analysis, it was found that overall acceptability of fruits viz., banana $\&$ sapota@10\% fruit incorporation was found to be highly acceptable. Whereas, it was found that overall acceptability of papaya yoghurt was found to be un acceptable @ 5, 10 and $15 \%$ fruit incorporation because of the watery consistency.

Table.4 Mean sensory characteristics on quality of probiotic fruit yoghurt

\begin{tabular}{|c|c|c|c|c|c|c|c|c|}
\hline Quality parameters & $\begin{array}{l}\text { Control } \\
\text { (Plain } \\
\text { probiotic } \\
\text { Yoghurt) }\end{array}$ & $\begin{array}{l}\text { Banana } \\
\text { fruit } \\
\text { Yoghurt } \\
(5 \%)\end{array}$ & $\begin{array}{l}\text { Banana } \\
\text { fruit } \\
\text { Yoghurt } \\
(10 \%)\end{array}$ & $\begin{array}{l}\text { Banana } \\
\text { fruit } \\
\text { Yoghurt } \\
(15 \%)\end{array}$ & Contro & $\begin{array}{l}\text { Sapota fruit } \\
\text { Yoghurt } \\
(5 \%)\end{array}$ & $\begin{array}{l}\text { Sapota } \\
\text { fruit } \\
\text { Yoghurt } \\
(10 \%)\end{array}$ & $\begin{array}{l}\text { Sapota fruit Yoghurt } \\
(15 \%)\end{array}$ \\
\hline Colour \& Appearance & $8.6 \pm 0.71$ & $8.3 \pm 0.66$ & $8.8 \pm 0.61$ & $\begin{array}{l}8.8 \pm \\
0.61\end{array}$ & $\begin{array}{c}8.6 \\
\pm 0.67\end{array}$ & $8.6 \pm 0.49$ & $8.7 \pm 0.46$ & $8.2 \pm 0.60$ \\
\hline Flavour & $8.5 \pm 0.50$ & $8.6 \pm 0.50$ & $8.7 \pm 0.47$ & $\begin{array}{l}8.5 \pm \\
0.50\end{array}$ & $\begin{array}{c}8.3 \\
\pm 0.63\end{array}$ & $8.4 \pm 0.49$ & $8.2 \pm 0.62$ & $8 \pm 0.64$ \\
\hline Consistency & $8.4 \pm 0.72$ & $8.2 \pm 0.81$ & $8.3 \pm 0.80$ & $\begin{array}{l}8.3 \pm \\
0.80\end{array}$ & $\begin{array}{c}8.4 \\
\pm 0.93\end{array}$ & $8.4 \pm 0.93$ & $8.4 \pm 0.93$ & $7.3 \pm 0.64$ \\
\hline Taste & $8.5 \pm 0.73$ & $8.3 \pm 0.91$ & $8.6 \pm 0.50$ & $\begin{array}{l}8.4 \pm \\
0.50\end{array}$ & $8 \pm 0.88$ & $8.1 \pm 0.69$ & $8 \pm 0.49$ & $7.8 \pm 0.75$ \\
\hline Overall acceptability & $8.4 \pm 0.72$ & $8.4 \pm 0.66$ & $8.6 \pm 0.50$ & $\begin{array}{l}8.4 \pm \\
0.50\end{array}$ & $\begin{aligned} & 8.4 \\
\pm & 0.67\end{aligned}$ & $8.3 \pm 0.79$ & $8.7 \pm 0.46$ & 7.80 .55 \\
\hline
\end{tabular}

Probiotic banana (10\%) and probiotic sapota yoghurt (10\%) had secured highest score for organoleptic values than the control yoghurt. Fruit yogurts were found most preferred to panelists than control yogurt. Higher solid and fiber content in fruit pulp may be associated with increasing viscosity and consequently improve the textural properties of fruit yogurts. Azza and O. I. El-B. (2013) reported better textural quality of stirred fruit yogurts than control. 
Int.J.Curr.Microbiol.App.Sci (2018) 7(3): 1440-1450

Table.5 Changes in viscosity $(\mathrm{cP})$ during storage

\begin{tabular}{|l|c|c|c|}
\hline Storage period & $\begin{array}{c}\text { Control (Plain } \\
\text { probiotic yoghurt) }\end{array}$ & $\begin{array}{c}\text { Probiotic banana } \\
\text { yoghurt }\end{array}$ & $\begin{array}{c}\text { Probiotic sapota } \\
\text { yoghurt }\end{array}$ \\
\hline Initial & 4450 & 11400 & 5200 \\
\hline $5^{\text {th }}$ day & 3700 & 8500 & 3700 \\
\hline $7^{\text {th }}$ day & 1200 & 7900 & 2900 \\
\hline $\mathbf{1 4}^{\text {th }}$ day & 700 & 7000 & 1900 \\
\hline
\end{tabular}

Table.6 Changes in syneresis during storage

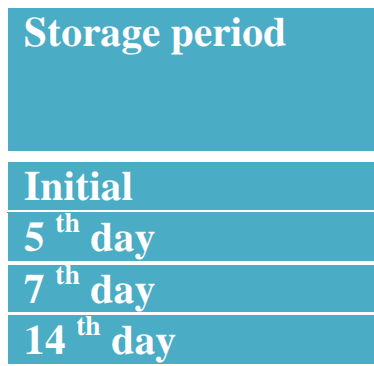

\begin{tabular}{|c|c|c|}
\hline $\begin{array}{c}\text { Control (Plain } \\
\text { probiotic } \\
\text { yoghurt) }\end{array}$ & $\begin{array}{c}\text { Probiotic banana } \\
\text { yoghurt }\end{array}$ & $\begin{array}{c}\text { Probiotic sapota } \\
\text { yoghurt }\end{array}$ \\
\hline 30 & 6.20 & 21.4 \\
\hline 32 & 6.35 & 22.07 \\
\hline 27 & 5.25 & 18.39 \\
\hline 9.87 & 5.11 & 16.0 \\
\hline
\end{tabular}

Table.7 Changes in $\mathrm{pH}$ during storage

\begin{tabular}{|l|}
\hline Storage period \\
\hline Initial \\
\hline 5 th day \\
\hline 7 th day \\
\hline 14 th day \\
\hline
\end{tabular}

\begin{tabular}{|r|}
\hline Contro \\
\hline probiotic \\
\hline 4.2 \\
\hline 4 \\
\hline 3.9 \\
\hline 3.7 \\
\hline od \\
\hline
\end{tabular}

Table.8 Changes in acidity during storage

\begin{tabular}{|l|}
\hline Storage period \\
\hline Initial \\
\hline $5^{\text {th }}$ day \\
\hline $7^{\text {th }}$ day \\
\hline $14^{\text {th }}$ day \\
\hline
\end{tabular}

\begin{tabular}{|c|c|c|}
\hline $\begin{array}{c}\text { Control (Plain } \\
\text { probiotic yoghurt) }\end{array}$ & $\begin{array}{c}\text { Probiotic banana } \\
\text { yoghurt }\end{array}$ & $\begin{array}{c}\text { Probiotic sapota } \\
\text { yoghurt }\end{array}$ \\
\hline 0.89 & 0.80 & 0.90 \\
\hline 1.29 & 0.85 & 1.17 \\
\hline 1.30 & 0.91 & 1.19 \\
\hline 1.34 & 0.93 & 1.20 \\
\hline
\end{tabular}

Table.9 Changes in TSS during storage

\begin{tabular}{|l|}
\hline Storage period \\
\hline Initial \\
\hline $5^{\text {th }}$ day \\
\hline $7^{\text {th }}$ day \\
\hline $14^{\text {th }}$ day \\
\hline
\end{tabular}

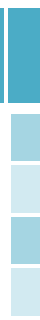

\begin{tabular}{|c|c|c|}
\hline Control & $\begin{array}{c}\text { Probiotic banana } \\
\text { yoghurt }\end{array}$ & $\begin{array}{c}\text { Probiotic sapota } \\
\text { yoghurt }\end{array}$ \\
\hline 15 & 15 & 16 \\
\hline 14 & 14 & 15 \\
\hline 13.5 & 13.5 & 14.5 \\
\hline 13 & 13 & 14 \\
\hline
\end{tabular}


Table.10 Changes in protein ( $\mathrm{g} \%$ ) during storage

\begin{tabular}{|l|c|c|c|}
\hline Storage period & Control & $\begin{array}{c}\text { Probiotic banana } \\
\text { yoghurt }\end{array}$ & $\begin{array}{c}\text { Probiotic sapota } \\
\text { yoghurt }\end{array}$ \\
\hline $\mathbf{0}$ days & 3.55 & 3.58 & 3.40 \\
\hline $\mathbf{5}^{\text {th }}$ day & 3.57 & 3.61 & 3.42 \\
\hline $\mathbf{1 4}^{\text {th }}$ day & 3.60 & 3.62 & 3.50 \\
\hline
\end{tabular}

Table.11 Changes in fat during storage

\begin{tabular}{|l|c|c|c|}
\hline Storage period & Control & $\begin{array}{c}\text { Probiotic banana } \\
\text { yoghurt }\end{array}$ & $\begin{array}{c}\text { Probiotic sapota } \\
\text { yoghurt }\end{array}$ \\
\hline $\mathbf{0}$ days & 3.05 & 3.06 & 3.04 \\
\hline $\mathbf{5}^{\text {th }}$ day & 3.02 & 3.04 & 3.02 \\
\hline $\mathbf{1 4}^{\text {th }}$ day & 2.97 & 3.02 & 3.01 \\
\hline
\end{tabular}

Table.12 Microbial load during storage

\begin{tabular}{|l|c|c|c|c|}
\hline Particulars & Storage period & $\begin{array}{c}\text { Control } \\
\text { (Probiotic } \\
\text { yoghurt) }\end{array}$ & $\begin{array}{c}\text { Probiotic } \\
\text { banana } \\
\text { yoghurt }\end{array}$ & $\begin{array}{c}\text { Probiotic } \\
\text { sapota } \\
\text { yoghurt }\end{array}$ \\
\hline Probiotic count & Initial day & $57 \times 10^{12}$ & $42 \times 10^{12}$ & $34 \times 10^{12}$ \\
\hline Yeast \& mold * & $14^{\text {th }}$ day & $9 \times 10^{8}$ & $21 \times 10^{8}$ & $15 \times 10^{8}$ \\
\hline & Initial day & - & - & - \\
\hline & $14^{\text {th }}$ day & - & - & - \\
\hline
\end{tabular}

*Yeast and mold count was nil at $10^{3}$ and $10^{5}$ dilutions.

Synersis reduction can be relating to absorption of unbound water.

Zekai Tarakci and Erdogan Kucukoner (2003) evaluated syneresis in fruit flavoured plain yoghurt (Cornelian, Morello Chery and Rose hip marmalade, grape molasses, date pulp, and control). The syneresis values of different fruit flavoured yoghurt were in the range of 24.83 to 27.20 . A significant increase in all of the samples after 6 days of storage was reported. The syneresis value of the present study was in accordance with the report of Zekai Tarakci and Erdogan Kucukoner (Table 6).

Salvador and Fiszman (2004) concluded that syneresis increased with storage time. Syneresis was observed to be increasing during storage of fruit flavored yoghurt (Kucukoner and Tarakci, 2003). Similarly, Salwa et al., (2004) reported that as the increase in concentration of carrot juice into the yoghurt the syneresis is also increased.

Upon physico chemical properties, the $\mathrm{pH}$ is higher in developed product when compared to control. Inclusion fruit pulp also alters the $\mathrm{pH}$ and acidity of yogurt. Fruit pulp addition increase the acidity due to the nature of pulp's acidity. $\mathrm{pH}$ of probiotic banana fruit yoghurt (4.6) was higher than control (4.2) and other probiotic fruit yoghurts. The $\mathrm{pH}$ values observed in this study was in agreement with the finding of Alula Tesfaye and Selvakumar Palaniappan (2015). Similar pH value (3.9 to 4.1) was observed by Zekai Tarakci and Erdogan Kucukoner 2003 in fruit flavoured 
plain yoghurt. A lowest $\mathrm{pH}$ (4.27) and highest $\mathrm{pH}$ (4.60) in control yogurt sample and $15 \%$ water melon incorporated yoghurt sample were recorded by Debashis Kumar Dutta Roy et al., (2016). In the present study a constant decrease in $\mathrm{pH}$ was observed in control yoghurt, followed by probiotic banana and sapota yoghurt during storage period. This might be attributed to the utilization of residual carbohydrate by viable microorganisms and production of lactic acid. Lactic acid can affect the $\mathrm{pH}$ value of yoghurt. If lactic acid is produced more, the $\mathrm{pH}$ of the yoghurt is lower. The decrease in $\mathrm{pH}$ was accompanied by an increase acidic taste of yogurt samples. The important criterion in probiotic drink is that it must have low $\mathrm{pH}, 4.5$ for maximum. The probiotic banana, sapota had an acceptable $\mathrm{pH}$ level at the end of the storage period (Table 7).

As the number of days increased, the $\mathrm{pH}$ values decreased. The extent of decrease in $\mathrm{pH}$ varies with the rate of growth of bacteria, interactions between yoghurt culture bacteria and other probiotic or spoilage microorganisms present in the product, additives present (e.g. fruits), storage temperatures and physicochemical properties such as total solids (TS) and total soluble solids (TSS) which provide fermentable substrate for lactic acid bacteria (LAB) and other spoilage bacteria such as coliforms. Several researchers have reported different degrees of decrease in $\mathrm{pH}$ under different storage conditions, as affected by the factors mentioned above (Yeganehzad et al., 2007; Akpan et al., 2007; Viljeon et al., 2003). As sugar sources finish, microorganisms begin to consume proteins and producing some products by microorganisms, which will result in $\mathrm{pH}$ increase after certain period of time (Frazier, W.C. and D.C. Westhhoff, 1995).

Fruit pulp addition increase the acidity due to the nature of pulp's acidity. An increasing trend in acidity was noticed in all the yoghurt samples. After 14 days of storage the acceptable acidity level was maintained in probiotic banana yoghurt $(0.93 \mathrm{~g} \%)$ followed by probiotic sapota yoghurt $(1.20 \mathrm{~g} \%)$. Similar increase in acidity of plain straw berry and plain apple yoghurt till $14^{\text {th }}$ day of storage was reported by Nafiseh Vahed et al., (2008) (Table 8).

Serrazanetti et al., (2013) stated that the presence of sugar and protein in the milk encourages the LAB to grow rapidly. LAB transform sugar into lactic acid, acetaldehyde, diacetyl, and formic acid, the accumulation of all these fermentation products corresponds to the increasing of acid level in curd samples. The present study confirmed that the increasing addition of fruit into yoghurt had increased the titratable acidity.

During fermentation the development of lactic acid under controlled conditions is essential for the formation of yoghurt gel network. On the contrary, development of acidity after the fermentation is not desired since it leads to wheying-off, textural defects, and excess sourness, which masks the perception of aroma compounds by the consumers. Similarly in the present study the acidity of yoghurt samples increases during storage which in turn it increases the wheying off. As the yoghurt becomes acidic it affects the viscocity in turn the acceptability of the product.

A gradual reduction in TSS was noted in all the yoghurt samples during storage. Maximum TSS content after 14 days of storage was noted in probiotic sapota sample followed by banana and control yoghurt samples. The reduction in TSS during storage may be due to the utilization of sugars and other metabolic activity by probiotics (Table 9).

Decreases in total soluble solids in yoghurts from $7.33 \%$ to $6.83 \%$ and $15.33 \%$ to $14.93 \%$, 
for corn milk and cow milk yoghurts respectively, have also been reported and these reductions have also been attributed to the utilization of sugar by the starter cultures (Vasiljevic and Jelen, 2002; Wang et al., 2002). The results obtained in the present study are in accordance with the results of Vasiljevic and Jelen (2002) and Wang et al., (2002).

The highest $(3.58 \%)$ and lowest $(3.40 \%)$ protein were found in probiotic banana yoghurt and probiotic sapota yoghurt sample respectively. The low protein content in fruit pulp than raw milk might be major cause for low protein content in probiotic fruit yoghurt (guava, sapota and mango). During storage a slight increases in protein content was observed. Debashis Kumar Dutta Roy et al., (2016) reported a protein content of $3.80 \%$ in control and $3.53 \%$ in $15 \%$ water melon incorporated yoghurt samples (Table 10).

The fat content of control and fruit yoghurt was decreased during storage in control and fruit yoghurt. The fat content of control yoghurt is on par with probiotic fruit yoghurt. Dinesh Meel1 and Drishti Kadiyan (2017) reported the fat content of sugar and stevia added yoghurt 2.53 and $2.63(\%)$ respectively and the fat content of market sample 4.30(\%) (Table 11).

The maximum probiotic count of $57 \times 10^{10}$ was observed in control sample followed by probiotic banana yoghurt $45 \times 10^{10}$ at initial day. After $14^{\text {th }}$ day of storage period lowest count of $9 \times 10^{8}$ was observed in control. The maximum probiotic count of $21 \times 10^{8}$ was observed in probiotic banana yoghurt after 14 days of storage period (Table 12). Developed acidity is one of the important factors that exert influence on the viability of probiotic bacteria in any cultured dairy products. In the present study desirable acidity was maintained in probiotic banana yoghurt than other samples. This might be the reason for higher viable count in probiotic banana yoghurt than other samples. No yeast and mold colony was grown in plates till the $14^{\text {th }}$ day of storage.

Effect of aloevera on probiotic was studied by Panesar and Shinde (2012) who reported the total viable count of probiotic was satisfactory. The population of probiotic i.e. Lactobacillus acidophilus and Bifidobacterium bifidium was above $10^{9}$ $\mathrm{cfu} / \mathrm{ml}$ during prolonged storage.

The probiotic yoghurt prepared using L.casei @ 2\% inoculum secured highest value for sensory score. Probiotic banana and probiotic sapota yoghurt @ 10\% incorporation obtained more acceptance by panelists, this was due to coordination between fruits and dairy products. The probiotic fruit yoghurt can be successfully stored up to 14 days with. It can be recommended to children and adolescence.

\section{References}

A.O.A.C (2000). Official methods of analysis. Association of Official Analytical Chemists International. Maryland, USA.

Akpan, U.G., Mohammed, A.D. and Aminu, I. 2007. Effect of preservative on the shelf life of yoghurt produced from soya beans milk. Leonardo Electronic Journal of Practices and Technologies 11: 131-142.

Amaya-Liano S. L., Martinez A. L. and Bustoe F. 2008. Acid thinned Jicama and maize starch as fat substitute in stirred yoghurt. LWT-Food Sci. and Technology, 41: 1274-1281.

Azza M. F. and O. I. El-B. 2013. Proteolytic Activity and Some Properties of Stirred Fruit Yoghurt Made Using Some Fruits Containing Proteolytic Enzymes. World Journal of Dairy \& Food Sciences, 8(1): $38-44$. 
Bhat JA, Naik MI and Tenguria RK.2013. Isolation of Lactic acid bacteria under low temperature for the preparation of yoghurt. Int. J. Appl. Bio pharmaceutical Technol. 4(1): 293-298.

Dinesh Meel and Drishti Kadiyan. 2017. Development of herb supplemented fruit yoghurt. International Journal of Advanced Scientific Research and Management, 2(7): 94-96.

Frazier, W.C. and D.C. Westhhoff, 1995. Food Microbiology. Mc Graw-Hill Book Company.

Kalab, M; 2000, Yoghurt: Electron microscopy. Foods under the microscope scimat.

Nafiseh Vahedi, Mostafa Mazaheri Tehrani and Fakhri Shahidi. 2008. Optimizing of Fruit Yoghurt Formulation and Evaluating Its Quality During Storage. American-Eurasian J. Agric. \& Environ. Sci., 3(6): 922-927.

Nongonierma A., Cayot P., Springett M., Le Quere J. L., Cachon R. and Voilley A. 2007. Transfers of small analytes in a multiphasic stirred fruit yoghurt model. Food Hydrocolloids, 21(2), 287-296.

Vasiljevic, T. and Jelen, P. 2002. Lactose hydrolysis in milk as affected by neutralizers used for the preparation of crude $\beta$-galactosidase extracts from Lactobacillus bulgaricus 11842. Innovative Food Science and Emerging Technologies 3: 175-184.

Viljoen, B.C., Lourens-Hattingh, A., Ikalafenga, B. and Peter, G.2003. Temperature abuse initiating yeast growth in yoghurt. Food Research International 36: 193-197.

Wang, Y. C., Yu, R. C. and Chou. C. C. 2002. Growth and survival of bifidobacteria and lactic acid bacteria during the fermentation and storage of cultured soymilk drinks. Food Microbiology 19: 501-508.

Yeganehzad, S., Mazaheri-Tehrani, M. and Shahidi, F. 2007. Studying microbial, physiochemical and sensory properties of directly concentrated probiotic yoghurt. African Journal of Agricultural Research 2 (8): 366- 369.

Zekai Tarakci and Erdogan Kucukoner. 2003. Physical, Chemical, Microbiological and Sensory Characteristics of Some Fruit-Flavored Yoghurt. YYÜ Vet Fak Derg 2003, 14(2): 10-14.

\section{How to cite this article:}

Meenakshi, V., Suganya and Umamaheswari, T. 2018. Formulation of Value Enriched Probiotic Fruit Yoghurt. Int.J.Curr.Microbiol.App.Sci. 7(03): 1440-1450.

doi: https://doi.org/10.20546/ijcmas.2018.703.172 